\title{
POTENSI AGRIBISNIS USAHA TANI KELAPA DI KABUPATEN SUMENEP
}

\author{
Imra'atut Tamimah, Ika Fatmawati, Arfinsyah Hafid Anwari \\ Program Studi Agribisnis Fakultas Pertanian, \\ Universitas Wiraraja Sumenep \\ e-mail: ika_agribisnis@yahoo.co.id
}

\begin{abstract}
ABSTRAK
Kelapa adalah salah satu komoditas di Wilayah Nusantara yang paling luas penyebarannya. Kelapa merupakan bagian yang melekat di kehidupan masyarakat dengan peran yang berbeda-beda, peran kelapa yaitu untuk memenuhi kebutuhan sosial dan budaya hingga untuk kepentingan ekonomi, sehingga kelapa dijuluki tree oflife, pohon kehidupan. Penelitian ini bertujuan yaitu : (1). Untuk mengetahui potensi sumber daya agribisnis kelapa di Kabupaten Sumenep. (2). Untuk mengetahui potensi pasar agribisnis kelapa di Kabupaten Sumenep. Penentuan lokasi penelitian dilaksanakan secara sengaja (purposive sampling) dengan mempertimbangkan bahwa Kabupaten Sumenep adalah salah satu Daerah sentra produksi kelapa dengan produktivitas yang terus meningkat dari tahun ke tahun. Metode pengumpulan data pada penelitian ini dilaksanakan dengan menggunakan data sekunder, yaitu data yang didapat secara tidak langsung melalui pelantara seperti data yang diambil dari literatur dan lembaga-lembaga terkait yang mempunyai hubungan dengan penelitian ini. Metode analisa data yang digunakan adalah analisis deskriptif kuantitatif yang meliputi analisis LQ, trend permintaan dan trend penawaran. Hasil analisis menunjukkan Sumber daya agribisnis tanaman kelapa di Kabupaten Sumenep memiliki potensi sebagai basis pertumbuhan dan memiliki keunggulan komparatif sehingga hasilnya selain bisa untuk memenuhi kebutuhan seluruh Kabupaten Sumenep juga bisa dikirim keluar Wilayah Kabupaten Sumenep. Potensi pasar agribisnis dapat terlihat dari penawaran dan permintaan kelapa di Kabupaten Sumenep pada tahun 2016 diperkirakan mencapai sebesar 43.069 ton dan 5.550 ton. Produksi kelapa mampu memiliki surplus (kelebihan) penawaran yang memenuhi di Kabupaten Sumenep.
\end{abstract}

Kata Kunci: Kelapa, LQ, Trend Penawaran, Trend Permintaan

\section{PENDAHULUAN}

Kelapa (Cocos nucifera $)$
adalah industri atau tanaman perkebunan yang berupa pohon batang lurus dari famili Palmae. Di negara-negara Asia banyak terdapat kelapa dengan menghasilkan 52.127 .000 ton $(85,32 \%)$ produksi kelapa dalam bentuk segar di dunia dengan luas \pm 9.361 .000 ha (2008). Di dunia Indonesia merupakan negara penghasil kelapa pada urutan ke-2 menurut data rata-rata Food Agricultural Organization 2004-2008 yang tersebar di Riau, Sulut, Jatim,
Jateng, Jabar, Sulteng, Sulsel, Lampung, Jambi dan Maluku.

Indonesia merupakan negara sebagai produsen terbesar didunia, kelapa Indonesia menjadi ajang bisnis raksasa mulai dari pengadaan sarana produksi (bibit, pupuk, pestisida, dll); aktivitas penunjangnya (keuangan, irigasi, transportasi, perdagangan, dan lainlain) dan proses produksi, pengolahan produk kelapa (turunan dari daging, tempurung, sabut, kayu, lidi, dan nira).

Kelapa adalah salah satu komoditas di Wilayah Nusantara yang paling luas penyebarannya. 
Kelapa merupakan bagian yang melekat di kehidupan masyarakat dengan peran yang berbeda-beda, peran kelapa yaitu untuk memenuhi kebutuhan sosial dan budaya hingga untuk kepentingan ekonomi, sehingga kelapa dijuluki tree oflife, pohon kehidupan.

Salah satu daerah penghasil komoditi kelapa yang cukup besar di Jawa Timur adalah Kabupaten Sumenep. Per tahun menghasilkan 1,5 miliar butir kelapa dari luas areal 300 ribu hektare. Nilai ekonomis produksi kelapa Jawa Timur total mencapai Rp 4,5 triliun jika per butir seharga Rp 3.000 . Kabupaten Sumenep dikenal sebagai sentra produksi kelapa dan juga telah ditetapkan sebagai musium kelapa Jawa Timur, karena banyaknya keanekaragaman varietas kelapa yang ada di Kabupaten Sumenep. Berdasarkan laporan tahunan data statistik perkebunan produksi kelapa di Kabupaten Sumenep sebesar $40.601,70 \mathrm{~kg}$ dan luas panen mencapai 31.936,89 hektar (BPS, 2015).

Tabel 1. Data Kelapa di Kabupaten Sumenep Tahun 2014.

\begin{tabular}{clrrr}
\hline No & \multicolumn{1}{c}{ Kecamatan } & $\begin{array}{c}\text { Produksi } \\
(\mathrm{kg})\end{array}$ & $\begin{array}{c}\text { Luas Panen } \\
(\mathrm{Ha})\end{array}$ & $\begin{array}{c}\text { Produktivitas } \\
(\mathrm{Kg} / \mathrm{Ha})\end{array}$ \\
\hline 1 & \multicolumn{1}{c}{2} & $1.555,74$ & \multicolumn{1}{c}{$1.183,26$} & \multicolumn{1}{c}{5} \\
\hline 1 & Pragaan & $1.913,51$ & $1.477,84$ & $1.294,79$ \\
2 & Bluto & $1.132,56$ & 875,23 & $1.294,01$ \\
3 & Saronggi & 193,67 & 148,45 & $1.304,61$ \\
4 & Gili genting & 151,72 & 117,00 & $1.296,75$ \\
5 & Talango & 248,06 & 187,86 & $1.320,44$ \\
6 & Kalianget & 638,26 & 491,15 & $1.299,53$ \\
7 & Kota & 334,17 & 245,28 & $1.399,11$ \\
8 & Btatuan & $2.371,86$ & $1.841,86$ & $1.287,76$ \\
9 & Lenteng & $2.041,86$ & $1.572,39$ & $1.298,57$ \\
10 & Ganding & $2.087,13$ & $1.600,61$ & $1.303,96$ \\
11 & Guluk Guluk & $1.584,51$ & $1.222,00$ & $1.296,66$ \\
12 & Pasongsongan & $1.550,70$ & $1.193,99$ & $1.298,76$ \\
13 & Ambunten & $1.265,27$ & 971,28 & $1.302,68$ \\
14 & Rubaru & $1.495,09$ & $1.146,58$ & $1.303,95$ \\
15 & Dasuk & $1.226,02$ & 943,34 & $1.299,65$ \\
16 & Manding & 928,91 & 732,98 & $1.267,30$ \\
17 & Batu putih & $2.316,64$ & $1.777,93$ & $1.303,00$ \\
18 & Gapura & $2.947,00$ & $2.258,39$ & $1.304,91$ \\
19 & Batang Batang & $2.212,13$ & $2.038,45$ & $1.085,20$ \\
20 & Dungkek & 822,77 & 629,75 & $1.306,52$ \\
21 & Nunggunong & 774,86 & 594,53 & $1.303,32$ \\
22 & Gayam & $2.393,38$ & $2.198,79$ & $1.088,50$ \\
23 & Raas & $2.734,10$ & $2.118,30$ & $1.290,70$ \\
24 & Sapekken & $2.010,66$ & $1.543,96$ & $1.302,28$ \\
25 & Arjasa & $1.005,21$ & 768,23 & $1.308,47$ \\
26 & Kangayan & $2.665,91$ & $2.057,47$ & $1.295,72$ \\
27 & Masalembu & $40.601,70$ & $31.936,89$ & $1.271,59$ \\
\hline & Jumlah total & & &
\end{tabular}

Sumber: Badan Pusat Statistik (BPS), 2015. 
Kabupaten

Sumenep

mempunyai keunggulan komperatif (comperative advantages) sebagai potensi investasi yang cukup menjanjikan yang bisa dikembangkan oleh masyarakat. Sebagian besar masyarakat yang bekerja terkonsentrasi disektor primer, banyak kesempatan yang bisa digarap menjadi suatu komoditi yang cukup menjanjikan, diantaranya adalah orientasi agribisnis. Secara ekonomis, produk-produk sektor primer dapat diproses dengan secara agribisnis, memiliki nilai jual yang relatif lebih tinggi dibandingkan dengan produk barang primer. Proses produksi yang terstandarisasi berdampak langsung pada nilai tambah atas produk yang bersangkutan sehingga akhirnya berdampak pada peningkatan harga jual dan keuntungan produsennya.

Meskipun potensinya begitu besar, pada kenyataannya kelapa belum bisa menjadi komoditas unggulan di Kabupaten Sumenep. Bermacam permasalahan masih dirasakan di tingkat petani, industri pengolah dan pada tingkat pemasaran. Beragam masalah yang dihadapi mulai dari teknis budidaya, skala usaha, teknologi pengolahan, pemasaran produk, sumber daya manusia, akses permodalan, infrastruktur, kesenjangan informasi dan dukungan kebijakan.

Sumber daya kelapa sesungguhnya perlu dioptimalkan pengelolaannya dan mempunyai potensi yang sangat besar sehingga kembali menjadi sebagai salah satu motor penggerak perekonomian nasional. Kelapa mempunyaii kontribusi dan peran strategis hampir pada semua bidang kehidupan, diantaranya yaitu dibidang ekonomi, pangan, kesehatan, energi, lingkungan, konstruksi, sosial budaya, seni dan kerajinan, serta pariwisata.

Pada umumnya petani memiliki tingkat pendidikan, wawasan, dan ekonomi yang masih rendah sehingga hal tersebut sangat mempengaruhi perkembangan usaha tani kelapa, demikian pula dengan asal muasal dari kebun tersebut. Petani yang mendapatkan kebun kelapa dari warisan biasanya hanya memungut hasilnya saja, tidak akan memperdulikan pemeliharaannya. Berbeda halnya dengan petani yang membangun kebun kelapa dengan menanam sendiri biasanya mereka mengurus kebunnya dengan baik. Keadaan yang demikian diperburuk lagi oleh karakter yang dimiliki tanaman kelapa. Dari luas areal kelapa di Indonesia, kelapa dalam lokal dengan mempunyai proporsi $95,8 \%$, dalam keadaan lingkungan tumbuh yang sesuai akan tetap berbuah walaupun tidak dipelihara. Banyak karakter lain yang tidak merangsang petani untuk melaksankan pemeliharaan.

Bermacam permasalahan yang masih melingkupi usaha perkelapaan baik dari sektor hulu maupun hilir serta sektor industri dan jasa penunjangnya belum diketahui secara sempurrna potensi perkembangan kelapa di Kabupaten Sumenep, maka dari itu perlu diatasi dan dibenahi secara terkoordinasi dan bersama secara baik.

Berdasarkan kenyataan yang dikemukakan diatas, peneliti merasa tertarik dan menganggap perlu mengadakan penelitian yang berjudul 
"Potensi Agribisnis Usahatani Kelapa di Kabupaten Sumenep"

Adapun tujuan yang bisat diperoleh dari penelitian ini adalah sebagai berikut: (1) Untuk mengetahui potensi sumber daya agribisnis kelapa di Kabupaten Sumenep. (2) Untuk mengetahui potensi pasar agribisnis kelapa di Kabupaten Sumenep.

\section{METODELOGI PENELITIAN}

\section{Lokasi Penelitian}

Lokasi penelitian dilaksanaknn secara sengaja (purposive sampling) (Nazir, 1989). Kabupaten Sumenep merupakan tempat dilakukannya penelitian dengan pertimbangan Kabupaten Sumenep merupakan salah satu Daerah sentra produksi kelapa dengan produktivitas yang selalu meningkat dari tahun ke tahun. Pada tahun 2015, luas areal tanaman kelapa di Kabupaten Sumenep adalah 31.936,89 hektar dan produksi kelapa di Kabupaten Sumenep sebesar $40.601,70 \mathrm{~kg}$.

\section{Metode Penelitian}

Metode deskriptif kuantitatif merupakan metode yang digunakan dalam penelitian ini. Metode deskriptif adalah metode yang memberikan suatu gambaran terhadap fenomena-fenomena, menguji hipotesa, memperoleh makna dan implikasi suatu masalah yang akan dipecahkan (Nazir, 1999).

\section{Metode Pengumpulan Data}

Metode pengumpulan data pada penelitian ini dilaksanakan dengan menggunakan data sekunder, yaitu data yang didapatkan secara tidak langsung melalui perantara seperti data yang diambil dari literatur dan lembaga-lembaga terkait yang mempunyai hubungan dengan penelitian ini.

\section{Metode Analisis Data}

Guna menguji tujuan yang telah diajukan sebelumnya, maka penelitian ini menggunakan Metode Analisa Data sebagai berikut :

Metode analisa yang digunakan untuk menjawab tujuan pertama menggunakan analisis deskriptif. Analisis potensi sumber daya digunakan untuk mengetahui potensi komoditas kelapa, untuk mengembangkan suatu komoditas pertanian sangat dibutuhkan dukungan sumberdaya alam, diantaranya sumber daya lahan, sumber daya air, sumber daya manusia, dan dengan menggunakan rumus LQ. Metode LQ (location quotient) ini digunakan untuk mengidentifikasi komoditas basis dan bukan basis pangan pada suatu Daerah. Teknik tersebut yaitu membandingkan antara kemampuan suatu Daerah dalam menghasilkan suatu komoditas dengan Daerah lain yang merupakan penghasil komoditas yang sama.

Konsep tersebut bisa diformulasikan sebagai berikut Warpani (dalam Endro, 2008) :

$$
\mathrm{LQ}=\frac{S i / N i}{S / N}=\frac{S i / S}{N i / N}
$$

Keterangan :

$$
\text { LQ = Besarnya koefisien }
$$

lokasi komoditas kelapa.

$\mathrm{Si}=$ Jumlah luas areal panen komoditas kelapa pada tingkat Kecamatan. S=Jumlah luas areal panen subsektor komuditas perkebunan tingkat Kecamatan. Ni 
$=$ Jumlah luas areal panen komoditas kelapa pada tingkat Kabupaten. $\mathrm{N}=$ Jumlah luas areal panen subsektor komoditas perkebunan tingkat Kabupaten.

Apabila LQ $>1$ berarti komuditas kelapa bisa digunakan sebagai basis pertumbuhan dan memiliki keunggulan komparatif dan bisa dikirim ke luar Kecamatan. Apabila LQ $=1$ berarti non basis bisa memiliki keunggulan komparatif tapi tidak bisa dikirim keluar Kecamatan. Apabila LQ $<1$ non basis tidak memiliki keunggulan komparatif dan tidak bisa dikirim ke luar Kecamatan.

Metode analisa yang digunakan untuk menjawab tujuan kedua dengan menggunakan analisis deskriptif. Untuk mengetahui potensi komoditas kelapa dilihat dari analisis pasar perlu diketahui perkembangan permintaan (demand side) dan penawaran (suply side) kelapa untuk beberapa tahun yang akan datang dengan menggunakan trend. Metode ini untuk melihat trend yaitu dari data deret waktu. Data yang digunakan minimal 5 tahun. Apabila jumlah data adalah genap, maka skor waktunya adalah ..., $-5,-3,-1,1,3$, $5, \ldots$ Dan jika jumlah data adalah ganjil, maka skor waktunya adalah $\ldots,-2,-1,0,1,2 \ldots$.

Metode kuadratik terkecil (least square method) digunakan untuk meramalkan trend garis lurus maupun trend tidak garis lurus (non linier). Mana yang akan digunakan apakah garis linier ataukah garis non linier tergantung dari skater diagram datanya.

Jika skater diagram datanya menunjukkan garis lurus (linier), maka sebaiknya digunakan trend garis linier. Persamaan metode trend linier adalah sebagai berikut (Harmono, 2011):

$$
\begin{aligned}
& \mathrm{Y}=\mathrm{a}+\mathrm{bX} \\
& \mathrm{Y}=\text { Variabel yang akan dibuat }
\end{aligned}
$$
garis trendnya.

$\mathrm{X}=$ Indeks veriabel waktu.

$\mathrm{a}=$ Intersep (nilai variable periode awal).

$\mathrm{b}=$ Slope/koefisien trend.

Keterangan:

$$
\begin{aligned}
& \text { Jika } \sum X=0 \\
& \mathrm{a}=\sum Y: \mathrm{n} \\
& \mathrm{b}=\sum X Y: \sum X^{2} \\
& \mathrm{Y}=\text { Jumlah permintaan. } \\
& \mathrm{n}=\text { Jumlah data/tahun } \\
& \mathrm{X}=\text { Variabel tahun (waktu). }
\end{aligned}
$$

Jika datanya tidak linier, data cenderung membentuk parabola maka metode prediksi peramalan dapat ditentukan dengan menggunakan metode trend kuadratik, dan apabila datanya berfluktuasi dan secara rata-rata meningkat dapat menggunakan metode eksponansial. Kedua rumus metode kuadratik dan eksponensial dapat dirumuskan sebagai berikut (Damaijati, 2009):

Persamaan metode trend kuadratik :

$$
Y=a+b X+c X^{2}
$$

Keterangan:

$$
\begin{aligned}
& \text { Jika } \sum X=0 \\
& \mathrm{a}=\left(\sum Y-\mathrm{c} \sum X^{2}\right): \mathrm{n} \\
& \mathrm{b}=\sum X Y: \sum X^{2} \\
& \mathrm{c}=\quad\left[n \sum X^{2} Y-\right. \\
&\left.\left\{\sum X^{2}\right\}\left\{\sum Y\right\}\right]:\left[n \sum X^{4}-\left\{\sum X^{2}\right\}^{2}\right] .
\end{aligned}
$$




\section{HASIL PENELITIAN DAN PEMBAHASAN \\ LQ (Location Quotient)}

LQ adalah suatu indeks untuk membandingkan pangsa sub Wilayah dalam aktifitas tertentu dengan pangsa total aktifitas tersebut dalam total aktifitas Wilayah. Digunakan untuk mengidentifikasi komoditas basis dan bukan basis pangan pada suatu Daerah. Teknik ini membandingkan antara kemampuan suatu Daerah dalam menghasilkan suatu komoditas dengan Daerah lain yang merupakan penghasil komoditas yang sama.

Tabel 2. Kecamatan di Kabupaten Sumenep yang Memiliki LQ>1

\begin{tabular}{clr}
\hline No & \multicolumn{1}{c}{ Kecamatan } & LQ>1 \\
\hline 1 & Ganding & 1,53 \\
2 & Guluk - Guluk & 1,56 \\
3 & Pasongsongan & 1,65 \\
4 & Ambunten & 1,17 \\
5 & Gapura & 1,27 \\
6 & Batang - Batang & 1,14 \\
7 & Dungkek & 1,17 \\
8 & Nonggunong & 1,74 \\
9 & Gayam & 1,31 \\
10 & Raas & 2,03 \\
11 & Sapeken & 1,90 \\
12 & Arjasa & 1,79 \\
13 & Kangayan & 1,79 \\
14 & Masalembu & 1,96 \\
\hline
\end{tabular}

Sumber: Data Sekunder diolah, 2016

Dari Tabel di atas Seluruh Kecamatan (27 Kecamatan) yang ada di Kabupaten Sumenep 14 (empat belas) Kecamatan memiliki LQ $>1$. LQ tertinggi adalah Kecamatan Raas sebesar 2,03 (lampiran 2) sedangkan LQ terendah ada di Kecamatan Batang-Batang sehingga dapat disimpulkan bahwa komoditas tersenbut menjadi basis atau menjadi sumber pertumbuhan. Komoditas mempunyai keunggulan komparatif, hasilnya tidak bisa memenuhi kebutuhan di Wilayah bersangkutan tetapi juga bisa di ekspor ke luar Wilayah.

Komoditas yang menghasilkan nilai LQ $>1$ adalah standar normatif untuk ditetapkan sebagai komoditas unggulan. Namun ketika banyak komoditas disuatu Wilayah yang menghasilkan LQ $>1$, sementara yang dicari hanya satu, maka yang harus dipilih adalah komoditas yang mendapatkan nilai LQ paling tinggi. Karena nilai LQ yang semakin tinggi disuatu Wilayah menunjukkan semakin tinggi pula potensi keunggulan komoditas tersebut.

Sedangkan 13 (tiga belas) Kecamatan diantaranya Pragaan, Bluto, Saronggi, Giligenting, Talango, Kalianget, Kota Sumenep, Batuan, Lenteng, Rubaru, Dasuk, Manding, dan Batu Putih memiliki nilai $\mathrm{LQ}<1$. LQ terendah berada di 
Kecamatan Giligenting dengan luas 0,14 dengan demikian dapat disimpulkan bahwa tanaman kelapa pada Kecamatan tersebut bukan merupakan basis pertumbuhan (non basis). Produksi komoditas kelapa disuatu Wilayah tersebut tidak bisa untukt memenuhi kebutuhan sendiri sehingga perlu adanya pasokan atau impor dari luar.

Bagi Wilayah kepulauan dari 7 (tujuh) Kecamatan semuanya memiliki LQ > 1 sedangkan untuk Wilayah daratan dari 20 (dua puluh) Kecamatan hanya 7 (tujuh) Kecamatan yang memiliki LQ > 1

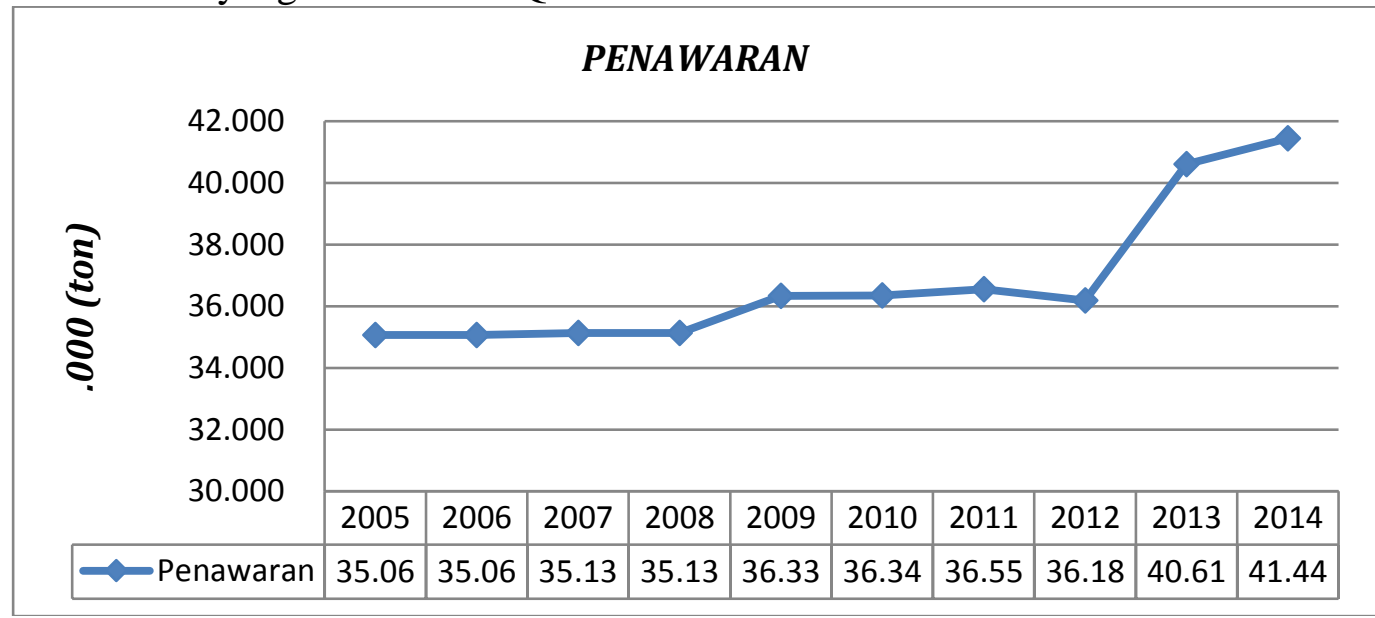

Gambar Grafik Penawaran Kelapa

Dengan melihat skater diatas, trend penawaran (produksi) menunjukkan kurva kuadratik sehingga lebih tepat menggunakan analisis trend kuadratik (non linier). Berikut ini disajikan pada tabel Tentang trend perkembangan produksi (penawaran) kelapa di Kabupaten Sumenep selama 10 tahun terakhir (2006-2015).

Dari tabel 3. trend penawaran dari tahun 2005 sampai dengan tahun 2014 semakin meningkat itu disebabkan karena meningkatnya luas areal panen pada tahun 2006 sebesar $5,981 \%$, sedangkan pada sedangkan sisanya 13 (tiga belas) Kecamatan memiliki LQ $<1$. Dengan demikian semua Wilayah kepulauan selain mampu untuk memenuhi kebutuhan sendiri, juga bisa mengirim kelebihan kelapa keluar Kecamatan.

\section{Trend Penawaran}

Trend penawaran kelapa dari tahun 2006 hingga tahun 2015 di Kabupaten Sumenep secara grafis bisa dilihat pada gambar di bawah ini : 
(tahun) sebesar $87,1 \%$ sehingga sisanya sebesar $12,9 \%$ dipengaruhi oleh variabel diluar model (diluar tahun). Sedangkan hasil analisis variannya (anova) menunjukkan bahwa nilai sig sebesar 0,001 atau lebih kecil dari $0,05(5 \%)$ berarti analisis trend dapat digunakan sebagai alat untuk meramalkan trend produksi kelapa pada tahun berikutnya. Hasil prakiraan trend produksi atau penawaran pada tahun 2016 sebesar 43.069.103 kg.

Tabel 3. Perkembangan Penawaran Kelapa di Kabupaten Sumenep selama Sepuluh Tahun Terakhir (2006 - 2015).

\begin{tabular}{cc}
\hline Tahun & Penawaran (Ton) \\
\hline 2005 & 35.068 \\
2006 & 35.068 \\
2007 & 35.132 \\
2008 & 35.132 \\
2009 & 36.339 \\
2010 & 36.342 \\
2011 & 36.557 \\
2012 & 36.184 \\
2013 & 40.610 \\
2014 & 41.422
\end{tabular}

Sumber: Data sekunder diolah, 2016

\section{Trend Permintaan}

Konsumsi kelapa di

Kabupaten Sumenep dihitung dari perkalian antara konsumsi Susenas dengan jumlah penduduk, jumlah penduduk Sumenep tahun 2006 sampai dengan tahun 2015 dapat dilihat sebagaimana dilampirkan pada (lampiran 6). Karena berdasarkan hasil Susenas konsumsi kelapa dalam bentuk satuan butir sedangkan proyeksi produksinya dengan satuan ton, maka perlu dilakukan konversi dari butir ke ton.
Mengacu pada pembakuan statistik perkebunan berbasis formulir elektronik (eForm), konversi kelapa dari butir ke kopra dengan satuan $\mathrm{kg}$ sebesar 20\%, dengan kata lain 1 butir kelapa menghasilkan 0,2 kg kopra atau 5 butir kelapa menghasilkan 1 $\mathrm{kg}$ kopra. Hasil perkembangan permintaan kelapa di Kabupaten Sumenep selama sepuluh tahun terakhir dari tahun 2006 sampai tahun 2015 disajikan pada tabel dibawah ini:

Tabel 4. Perkembangan Permintaan Kelapa di Kabupaten Sumenep

\begin{tabular}{lr}
\hline Tahun & \\
\hline 2005 & Permintaan (ton) \\
2006 & 12.534 \\
2007 & 11.159 \\
2008 & 12.122 \\
2009 & 10.341 \\
2010 & 9.346 \\
2011 & 8.640 \\
2012 & 7.819 \\
2013 & 7.312 \\
2014 & 6.473 \\
\hline
\end{tabular}

Sumber: Data sekunder diolah, 2016 
Dari tabel diatas bahwa trend permintaan dari tahun 2005 sampai dengan tahun 2014 menurun itu disebabkan karena turunnya konsumsi kelapa perkapita / tahun yang diantaranya dipengaruhi oleh harga konsumen. Berdasarkan Pusdatin 2014, perkembangan harga produsen kelapa belum dikupas pada tahun 2002-2012 cenderung naik dengan rata-rata pertumbuhan sebesar $9,88 \%$ per tahun. Tahun 2002 harga kelapa belum dikupas ditingkat produsen sebesar Rp. 750 per butir kemudian naik menjadi Rp. 1.848 per butir pada tahun 2012 . Harga kelapa di tingkat produsen tertinggi dicapai pada tahun 2012 dengan pertumbuhan $3,59 \%$ terhadap tahun 2011.
Sedangkan perkembangan harga konsumen untuk kelapa belum dikupas cenderung naik dengan ratarata pertumbuhan $12,15 \%$ per tahun. Tahun 2002 harga kelapa di tingkat konsumen Rp. 1.103 per butir dan naik menjadi 3.062 per butir. Harga kelapa di tingkat konsumen tertinggi dicapai pada tahun 2012 dengan pertumbuhan $0,33 \%$ terhadap tahun sebelumnya. Secara rinci harga kelapa tingkat konsumen dan tingkat produsen pada lampiran 6 .

Trend permintaan kelapa dari tahun 2006 hingga tahun 2015 di Kabupaten Sumenep secara grafis bisa dilihat pada gambar di bawah ini

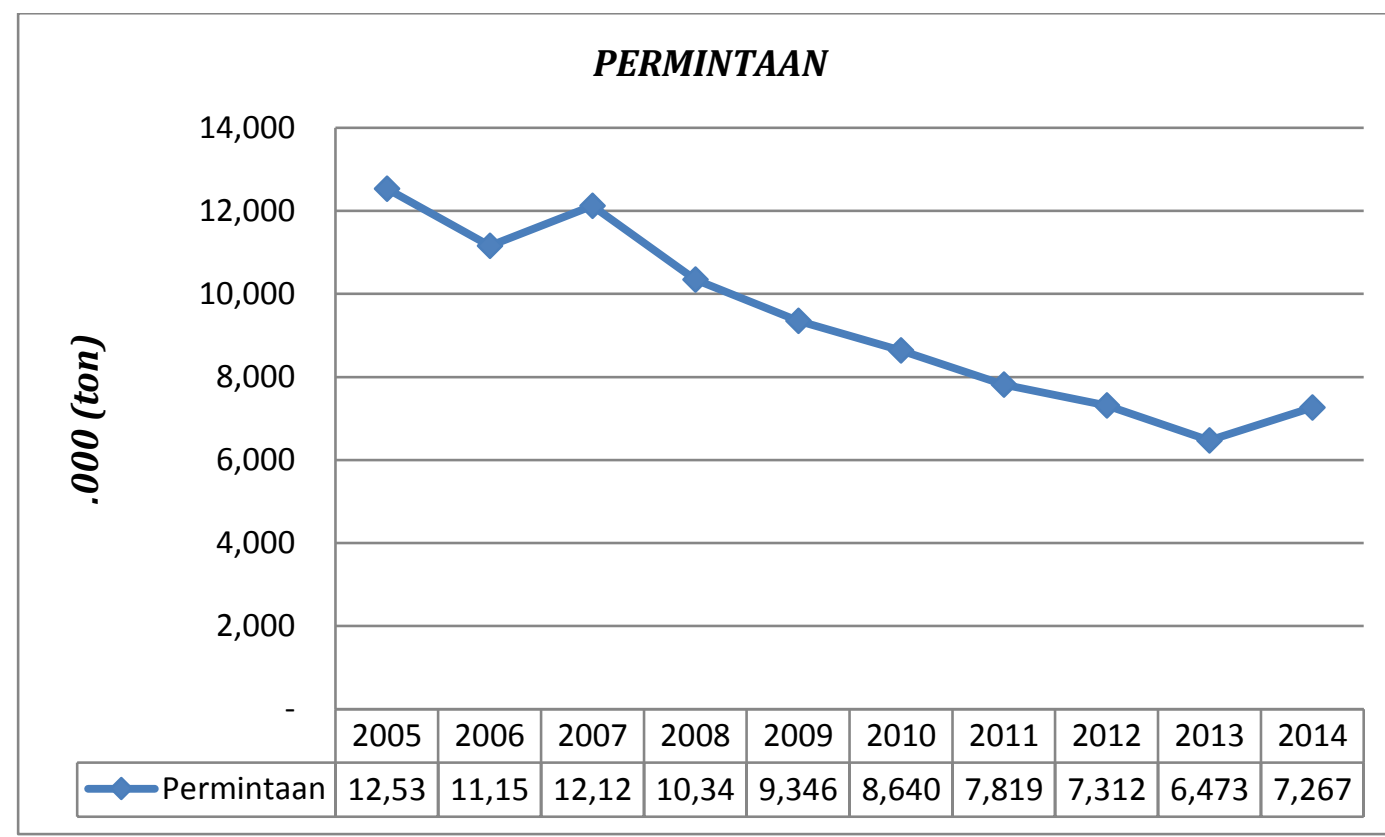

Gambar Grafik Permintaan Kelapa

Perkembangan permintaan kelapa di Kabupaten Sumenep bisa dianalisis yaitu dengan menggunakan metode trend linier (lurus) berdasarkan data time series pada tabel di atas.
Hasil analisis trend permintaan kelapa menggunakan metode regresi linear / Lurus (lampiran 8) dapat dilihat bahwa nilai $\mathrm{R}$ Square $=0,921$ berarti variabel dependen (permintaan) 
dipengaruhi oleh indeks (tahun) sebesar 92,1\% sehingga sisanya sebesar $7,9 \%$ dipengaruhi oleh variabel diluar model (diluar tahun). Sedangkan hasil analisis variannya (anova) menunjukkan bahwa nilai sig sebesar 0,000 atau lebih kecil dari 0,05 (5\%) berarti analisis trend linier dapat digunakan sebagai alat untuk meramalkan trend permintaan kelapa pada tahun berikutnya. Berikut diperoleh persamaan regresinya $=\mathrm{Y}=$ 9.301.802.083 + 340.994.44 X. Hasil prakiraan trend permintaan kelapa pada tahun 2016 sebesar 5.550.863 $\mathrm{kg}$ dapat dilihat pada lampiran 9.

\section{Perbandingan Antara Penawaran Dan Permintaan}

Perbandingan antara trend penawaran dengan trend permintaan di Kabupaten Sumenep secara grafis dapat dilihat pada gambar berikut:

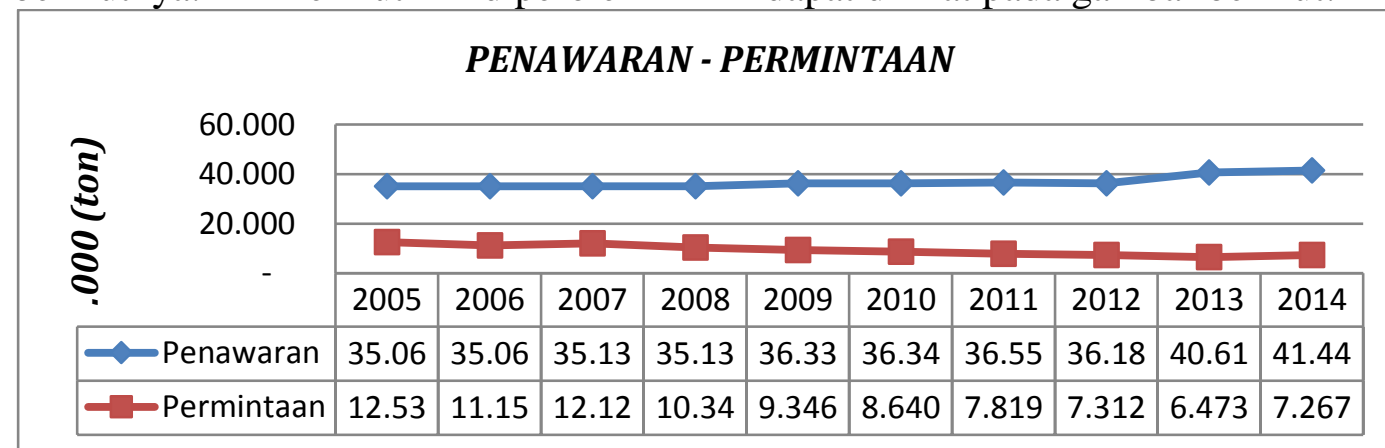

Gambar Grafik Perbandingan Antara Penawaran dan Permintaan

Dari gambar diatas dapat dilihat bahwa selama 10 tahun mulai dari tahun 2006 sampai 2015 terjadi surplus (kelebihan) penawaran hal ini disebabkan selain meningkatnya jumlah produksi kelapa juga semakin menurunnya jumlah permintaan.

Surplus penawaran terendah terjadi pada tahun 2005 sebesar $(35.068,66-12.534,815)=22,533$ ton dan surplus penawaran tertinggi terjadi pada tahun 2013 sebesar $(41.422,92-6.473 .387)=34.155$ ton dengan demikian maka kebutuhan Sumenep bisa terpenuhi dan kemudian dapat disimpulkan bahwa Kabupaten Sumenep memiliki produksi kelapa yang tidak hanya mampu untuk memenuhi di Kabupaten Sumenep akan tetapi bisa dikirim keluar Daerah.

\section{KESIMPULAN DAN SARAN}

\section{Kesimpulan}

Berdasarkan hasil penelitian dan analisis potensi agribisnis usahatani kelapa di Kabupaten Sumenep yang telah dilakukan, maka dapat diperoleh kesimpulan sebagai berikut : (1) Sumber daya agribisnis tanaman kelapa di Kabupaten Sumenep memiliki potensi sebagai basis pertumbuhan dan memiliki keunggulan komparatif sehingga hasilnya selain bisa untuk memenuhi kebutuhan seluruh Kabupaten Sumenep juga bisa dikirim keluar Wilayah Kabupaten Sumenep. (2) Potensi pasar agribisnis dapat terlihat dari penawaran dan permintaan kelapa di Kabupaten Sumenep pada tahun 2016 diperkirakan mencapai sebesar 43.069 ton dan 5.550 ton. Produksi kelapa mampu memiliki surplus (kelebihan) penawaran yang memenuhi di Kabupaten Sumenep. 


\section{Saran}

Luas areal panen tanaman kelapa hendaknya dapat lebih ditingkatkan melalui upaya peremajaan tanaman yang sudah tidak produktif lagi sehingga potensi sumber daya agribisnis kelapa sebagai basis pertumbuhan dapat tetap dipertahankan.

\section{DAFTAR PUSTAKA}

Badan Pusat Statistik Sumenep. 2006. Sumenep Dalam Angka. Sumenep : BPS.

\begin{tabular}{|c|}
\hline $\begin{array}{l}\text { Sumenep Dalam } \\
\text { Sumenep : BPS. }\end{array}$ \\
\hline Sumenep Dalam \\
\hline
\end{tabular}

2009.
Sumenep Dalam Angka. Sumenep : BPS.

Sumenep Dalam Angka.
Sumenep:
Sumenep : BPS.

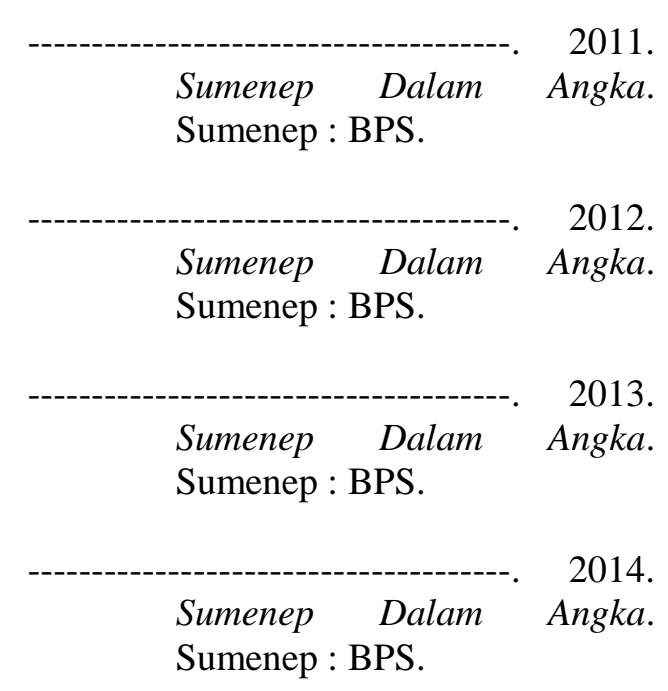

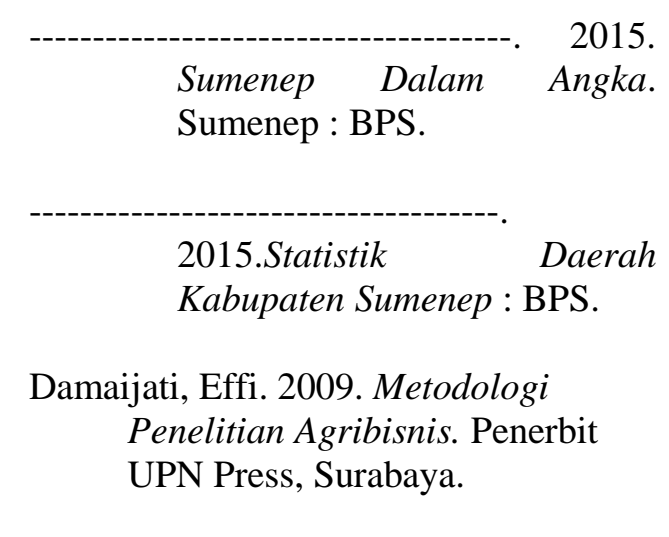

Fatmawati, Ika dan Didik. 2015. Potensi Rumput Laut di Kabupaten Sumenep. [Jurnal Pertanian Cemara]. Volume 12, Nomer 1 : 1-9. Universitas Wiraraja Sumenep.

Harmono. 2011. Manajemen Keuangan Berbasis Balanced Scorecard Pendekatan Teori, Kasus, dan Riset Bisnis. Penerbit Bumi Aksara, Jakarta.

Hasbi, Husaini. 2009. Budidaya Tanaman Kelapa. http://sekolah.ptkpt.net/_g.php?_g $=1$ hti forum $\&$ Bid $=1079$. diakses 15 April 2015.

Nazir. 1999. Metodologi Penelitian. Ghalia Indonesia, Jakarta.

Nugrah, Aditya. 2013. Analisis potensi ekonomi Kabupaten dan kota di Provinsi Daerah Istimewa Jakarta. [Skripsi] Universitas Islam Negri Syarif Hidatullah Jakarta.

Patah, Iyung. 2006. Panduan Lengkap Kelapa Sawit Manajemen Agribisnis dari Hulu Hingga Hilir. Penerbit Penebar Swadaya.

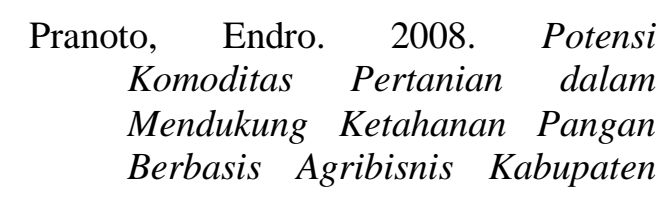


Banyumas. [Tesis] Program Pascasarjana Universitas Diponegoro Semarang.

Pusdatin. 2014. Outlook Komoditi Kelapa. Pusat data dan sistem Informasi Pertanian Sekretariat Jenderal-Kementrian Pertanian. ISSN 1907-1507

Rukmana, Rahmat. 2003. Ttg. Aneka Olahan Kelapa. Penerbit Kanisius. Yogyakarta. Googlebooks.

Saragih, Bungaran. 1999. Agribisnis Paradigma Baru Pembangunan Ekonomi Berbasis Pertanian. CV Nasional, Jakarta.

Setyamidjaja, Djoehana. 1984. Bertanam Kelapa Budidaya dan Pengolahannya. Penerbit Kanisius.

Siagian Sondang. 2003. Teori dan Praktek Kepemimpinan. Penerbit Rineka Cipta. Jakarta.

Sirait, Samuel Hermanto. 2013. Agribisnis komoditi tanaman kelapa (cocos nucifera) di Indonesia.

http://hutanb2011.blogspot.co.id/2 013/06/agribisnis-komodititanaman-kelapa.html. di akses 11 April 2016.

Soekartawi. 1995. Ilmu Usahatani. Jakarta: Raja Grafindo Persada.

Uyanto, Stanislaus. 2009. Pedoman Analisis Data Dengan SPSS. Yogyakarta. Graha Ilmu.

Wibowo, Ega Wisnu. 2010. Analisis Potensi Agribisnis Kopi di Desa Sidomuncul Kecamatan Silo Kabupaten Jember. [Skripsi] Universitas Jember. 